\title{
HUBUNGAN ANTARA RELIGIOSITAS DENGAN AGRESIVITAS PADA KOMUNITAS PEMUDA GEREJA
}

\author{
Eirena Fiola Wijaya ${ }^{1}$, \\ Yonathan Aditya, \\ David Matahari \\ Fakultas Psikologi \\ Universitas Pelita Harapan \\ Jl. MH. Thamrin Boulevard, Lippo Karawaci \\ Tangerang 15811, Indonesia \\ ${ }^{1}$ e-mail: eirenafiola@gmail.com
}

\begin{abstract}
A lot of individuals have lived their lives with a strong attachment towards religion; however some of them still have a high aggressive behavior. This phenomenon is also evident in the youth communities within the church. The core teaching of the Christianity is love, in which love is supposed to inhibit individuals to initiate aggressive behavior. This study aims to explore the correlation between religiosity, which has two components (intrinsic religiosity orientation and extrinsic religiosity orientation), towards aggressive behavior in youth communities within the church. This study used quantitative method. To obtain and collect the data, we used the aid of questionnaire distributed through purposive technique towards 87 subjects. The instruments included the Verbal Aggressive Scale for the aggressive behavior, the I/E-R Scales to measure religious orientation, and Faith Development Scale to measure the development of faith in each individual. The result of this research pointed out that there is no significant correlation between intrinsic religious orientation and aggressive behavior and that is a positive correlation between extrinsic religious orientation and aggressive behavior.
\end{abstract}

Keywords: intrinsic religiosity; extrinsic religiosity; aggressive behavior; Christianity; development of faith

\begin{abstract}
Abstrak - Banyak individu yang memiliki hidup dengan keterkaitan yang erat dengan agama, namun di sisi lain perilaku agresivitas mereka tetap tinggi. Fenomena ini juga terjadi dalam komunitas pemuda gereja. Inti dari ajaran agama Kristen adalah kasih, di mana idealnya kasih tersebut menahan individu untuk tidak melakukan perilaku agresif. Untuk menjelaskan fenomena ini, dilakukan penelitian mengenai hubungan antara religiositas, yang di dalamnya terdiri dari orientasi religiositas intrinsik dan ekstrinsik, dengan agresivitas pada pemuda gereja. Penelitian ini menggunakan metode kuantitatif. Pengumpulan data dilakukan dengan kuesioner di mana sampel diambil dengan teknik purposive sampling kepada 87 responden. Alat ukur yang digunakan dalam penelitian ini adalah Verbal Aggressiveness Scale untuk mengukur agresivitas, I/E-R Scales untuk mengukur
\end{abstract}


orientasi religiositas, dan Faith Developmental Scale untuk mengukur perkembangan iman. Hasil penelitian menunjukkan tidak adanya korelasi yang signifikan antara religiositas intrinsik dengan agresivitas, namun terdapatnya korelasi positif antara religiositas ekstrinsik dengan agresivitas.

Kata Kunci: religiositas intrinsik; religiositas ekstrinsik; agresivitas; Kristen; perkembangan iman

\section{PENDAHULUAN}

Tindakan kekerasan bukan merupakan hal yang sulit untuk ditemukan. Dari bulan Januari 2016 hingga Februari 2016, tercatat dalam data Jaringan Nasional Advokasi Pekerja Rumah Tangga (Jala PRT) telah terdapat 103 kasus kekerasan terhadap Pekerja Rumah Tangga (PRT), yang bila dihitung kembali, terdapat dua sampai empat PRT yang mengalami kekerasan setiap harinya (Muslim, 2016). Data ini menunjukkan bahwa dalam setiap harinya kekerasan terjadi. Selain itu, tindakan-tindakan kekerasan yang terjadi juga mudah dilihat dengan adanya media televisi. Ariyani (2012) mengungkapkan bahwa secara sadar maupun tidak, televisi telah turut mensosialisasikan tindakan kekerasan.

Tindakan kekerasan ternyata sudah menjadi suatu hal yang tidak asing dalam komunitaskomunitas tertentu yang dalam hal ini adalah komunitas gereja. Hal tersebut dapat dilihat dari apa yang diungkapkan oleh Green (1972) bahwa salah satu penyakit dalam gereja adalah Glossolistis. Bila dikaitkan dalam gereja atau keagamaan, Glossolistis diartikan sebagai penyakit yang suka membicarakan orang atau bergosip di dalam gereja, sehingga menimbulkan adanya individuindividu yang terluka hatinya karena hal tersebut.

Hal tersebut juga didukung oleh salah satu fenomena kekerasan yang terjadi dalam komunitas pemuda gereja di kawasan Lippo Karawaci. Berdasarkan wawancara yang dilakukan dengan salah satu gembala sidang dari gereja A yang berada di kawasan Lippo Karawaci, beliau melihat tingkat agresivitas yang dilakukan oleh pemuda di gerejanya cukup banyak, yakni berkisar antara 50 sampai 70 persen yang biasanya diwujudkan dalam bentuk verbal (Kawet, Komunikasi Personal, 2015).

Berdasarkan data-data di atas, dapat dilihat bahwa kekerasan juga dapat terjadi di dalam gereja. Dalam bidang psikologi, dapat disimpulkan bahwa kekerasan merupakan suatu wujud dari agresivitas. Menurut Myers (2013), agresi adalah perilaku fisik maupun verbal yang bertujuan untuk menyakiti seseorang. Dalam penelitian ini, agresivitas yang akan diteliti lebih difokuskan kepada agresi secara verbal. Individu yang memiliki agresivitas verbal cenderung menyerang konsep diri orang lain dan juga berusaha untuk menyakiti serta menimbulkan luka psikologis pada 
orang lain (Infante \& Wigley, dalam Daly, 2002). Perilaku agresif ini dapat dipicu oleh beberapa faktor, yakni: amarah, faktor biologis, kesenjangan generasi, lingkungan, frustrasi, pendisiplinan yang keliru, dan paparan terhadap kekerasan (Sarwono, 2005). Geen (1990) juga mengungkapkan bahwa latar belakang individu, yang salah satunya adalah nilai personal, dapat meningkatkan kecenderungan seseorang melakukan perilaku agresif.

Bila mengacu kepada salah satu hal yang meningkatkan perilaku agresif, sebagaimana diungkapkan oleh Geen (1990), yakni nilai-nilai (values) personal, maka untuk dapat mengatasi perilaku agresif yang kian meningkat salah satunya adalah dengan memperbaiki nilai-nilai yang dimiliki oleh individu. Watkins (2003) mengungkapkan bahwa banyak nilai yang dipelajari dari kegiatan keagamaan. Selain itu, pengajaran serta prinsip keagamaan juga mengandung nilai moral yang mengajarkan individu untuk hidup dan berperilaku dengan sewajarnya dan dalam kasih (Flannery, 1997). Ancok dan Suroso (2001) mengungkapkan bahwa religiositas merupakan suatu dimensi yang beragam, mencakup bagaimana individu melakukan suatu kegiatan yang didorong oleh kekuatan supranatural, yang di dalamnya termasuk kegaiatan beribadah.

Allport (1950) mengungkapkan bahwa terdapat dua jenis orientasi religiositas, yaitu orientasi religiositas intrinsik dan ekstrinsik. Religiositas ekstrinsik mengacu kepada penggunaan agama untuk mendapatkan keuntungan bagi diri sendiri, seperti dukungan sosial, kepuasan individu, dan juga hal lainnya. Individu yang memiliki orientasi religiositas ekstrinsik akan cenderung menerima nilai-nilai yang juga dipegang oleh komunitasnya karena ia menempatkan hal itu sebagai dukungan sosial. Di sisi lain, orientasi religiositas intrinsik lebih menggambarkan bagaimana hubungan pribadi dengan Tuhan, komitmen pribadi untuk hidup sesuai dengan apa yang diajarkan keagamaan yang berasal dari diri sendiri, serta menggambarkan adanya internalisasi nilai-nilai dalam keagamaan itu sendiri. Bila individu memiliki religiositas intrinsik, maka individu akan cenderung menilai suatu hal berdasarkan prinsip-prinsip keagamaan yang tentu mengajarkan hal baik.

Beberapa hasil penelitian menemukan bahwa agama dapat mendorong individu memiliki sikap yang baik, terutama dalam hal sosial (Steensland dkk., 2000). Watkins (2003) juga mengungkapkan bahwa semakin tinggi religiositas yang dimiliki oleh individu, maka semakin rendah tingkat agresivitas individu tersebut. Umasugi (2013) dalam penelitiannya mengungkapkan bahwa terdapat korelasi negatif antara religiositas dan regulasi emosi dengan kecenderungan perilaku bullying. Hasil penelitian ini pada umumnya menunjukkan bahwa semakin tinggi tingkat religiositas yang dimiliki oleh individu, maka semakin rendah tingkat agresivitasnya. Namun saja, hal ini tampak tidak sesuai dengan kenyataan yang telah dipaparkan di awal tulisan ini. Oleh karena itu perlu dilakukan penelitian lebih lanjut. 
Responden dalam penelitian ini dipilih berbeda dari penelitian sebelumnya yang dilakukan oleh Watkins (2003) dan Umasugi (2013), yakni pada komunitas keagamaan. Hal tersebut karena dalam kelompok keagamaan, nilai dan ajaran agama tentu menjadi hal yang utama, dan hal tersebut memengaruhi bagaimana individu semakin terpapar dengan nilai dan ajaran agama. Di sisi lain, responden yang akan diteliti adalah individu pada tahap emerging adulthood, yakni berusia 18 sampai 25 tahun (Arnett, 2004), yang termasuk ke dalam kelompok pemuda gereja. Responden dipilih karena terdapatnya karakteristik yang menarik, yakni dari segi moralitas, responden telah memiliki kontrol internal sehingga tidak hanya dipengaruhi oleh lingkungan luar (Kohlberg, dalam Papalia \& Feldman, 2012). Selain itu, agresivitas yang dimiliki pun cenderung meningkat, khususnya hostile aggression (Coie \& Dodge, dalam Papalia \& Feldman, 2012), yang lebih banyak terwujud dalam bentuk verbal (Pellegrini \& Archer, dalam Papalia \& Feldman, 2012). Selain itu, pemilihan kelompok komunitas pemuda juga dikarenakan bahwa usia individu yang pada umumnya masuk ke dalam komunitas pemuda gereja adalah 18-28 tahun (Ariwibowo, Komunikasi Personal, 2016), sehingga usia emerging adulthood pun termasuk di dalamnya dan dengan demikian dapat dikatakan pula bahwa individu yang tergolong ke dalam komunitas pemuda gereja memiliki karakteristik seperti pada individu dengan tahap emerging adulthood.

\section{Hubungan antara Religiositas dengan Agresivitas}

Individu yang berada pada tahap emerging adulthood telah berada pada tahap postconventional morality, di mana ia sudah mampu memiliki kontrol internal dan melakukan penilaian berdasarkan prinsip yang dimiliki dalam menentukan perilakunya (Kohlberg, dalam Papalia \& Feldman, 2012). Prinsip tersebut dapat diperoleh dari kegiatan agama yang dijalani oleh individu (Watkins, 2003). Dalam menjalankan kegiatan keagamaan, individu dapat memiliki orientasi tertentu, baik intrinsik maupun ekstrinsik.

Orientasi religiositas yang dimiliki oleh individu dapat dilihat dari tahap perkembangan iman yang dimiliki oleh individu berdasarkan karakteristik dari setiap tahap yang ada. Tahap perkembangan iman terdiri dari Infancy and Undifferentiated Faith, Intuitive Projective Faith, Mythic Literal Faith, Synthetic Conventional Faith, Individuative Reflective Faith, Conjunctive Faith, dan Universalizing Faith (Fowler, 1981). Berdasarkan karakteristik yang ada, semakin tinggi tahapannya, maka individu akan semakin memiliki orientasi religiositas intrinsik.

Individu yang berada pada masa dewasa muda biasanya berada pada tahap individuative reflective faith. Individu pada tahap ini sudah mampu memahami bahwa identitas dirinya bukan lagi dibentuk dari suatu hal di luar dirinya, namun merupakan suatu proses internal dalam dirinya 
sendiri (Fowler, 1981). Pada tahap ini individu mengartikan simbol-simbol yang ada kepada hal yang lebih konseptual. Individu juga telah mampu untuk mengkritisi kepercayaan yang telah ia percaya yang dapat diperoleh dari berbagai hal (Fowler, 1981) serta bersikap independen dari otoritas eksternal dan norma kelompok (Papalia \& Feldman, 2012).

Individu dengan orientasi religiositas intrinsik akan cenderung memiliki hubungan pribadi dengan Tuhan, komitmen pribadi untuk hidup sesuai dengan apa yang diajarkan kegamaan, serta menginternalisasi ajaran agama itu; sedangkan individu dengan orientasi religiositas ekstrinsik akan lebih menggunakan agama atau komunitas keagamaaan yang ada sebagai dukungan sosial bagi individu di dalamnya (Allport, 1950). Mengacu kepada hal tersebut, maka individu dengan orientasi religiositas intrinsik akan cenderung tidak melakukan perilaku agresif karena individu telah menginternalisasi ajaran agama, yang dalam agama Kristen, nilai utama yang diajarkan adalah kasih (Candawasa, 2013). Namun di sisi lain, bagi individu dengan orientasi religiositas ekstrinsik yang berada pada lingkungan dengan agresivitas yang cukup nyata, kecenderungan melakukan konformitas dapat terjadi demi mempertahankan dukungan sosial dari kelompok keagamaannya.

\section{Hipotesis Penelitian}

Berdasarkan teori, serta data yang telah dipaparkan, maka hipotesis yang akan diuji lebih lanjut dalam penelitian ini adalah sebagai berikut:

$H_{l}$ : Terdapat hubungan negatif yang signifikan antara orientasi religiositas intrinsik dengan agresivitas pada komunitas pemuda gereja.

$\mathrm{H}_{2}$ : Terdapat hubungan positif yang signifikan antara orientasi religiositas ekstrinsik dengan agresivitas pada komunias pemuda gereja.

\section{METODE}

\section{Partisipan}

Populasi dalam penelitian ini adalah anggota komunitas pemuda gereja di daerah Tangerang. Dalam mengambil sampel untuk penelitian ini, peneliti menggunakan teknik non-probabilitas jenis purposive sampling. Purposive sampling adalah pemilihan sampel dengan terlebih dahulu melakukan penilaian bahwa individu yang akan dijadikan sampel memiliki karakteristik yang sama dengan area atau pun dengan populasi yang akan diteliti (Kerlinger \& Lee, 2000). Karakteristik tersebut adalah individu dengan usia 18-25 tahun serta merupakan anggota dari salah satu komunitas pemuda gereja di kawasan Villa Permata dan Taman Ubud, Lippo Karawaci. Peneliti memilih empat dari delapan komunitas pemuda gereja di kawasan Villa Permata dan Taman Ubud 
untuk dijadikan sampel dalam penelitian ini. Dari empat komunitas pemuda gereja yang peneliti pilih tersebut, diperoleh 87 responden yang berpartisipasi dalam penelitian ini.

\section{Desain}

Penelitian menggunakan pendekatan kuantitatif non-eksperimental. Selain itu, untuk menjawab pertanyaan penelitian digunakan teknik korelasional. Penelitian ini juga menggunakan desain cross-sectional.

\section{Instrumen Penelitian}

Peneliti menggunakan kuesioner sebagai alat ukur dalam penelitian ini, yakni alat ukur orientasi religiositas, alat ukur agresivitas, dan alat ukur tahapan perkembangan iman. Alat ukur orientasi religiositas yang digunakan adalah I/E-R Scales yang dikembangkan oleh Gorsuch dan McPherson (1989). I/E-R Scales terdiri dari 14 butir yang mengukur tiga dimensi, yakni orientasi intrinsik ( 8 butir), orientasi ekstrinsik sosial ( 3 butir), dan orientasi ekstrinsik personal (3 butir). Dalam penelitian ini, uji reliabilitas menghasilkan koefisien Alpha Cronbach dimensi orientasi intrinsik sebesar .750 dengan validitas butir berkisar dari .378 hingga .560. Pada Reliabilitas dimensi orientasi ekstrinsik sosial, koefisien Alpha Cronbach yang dimiliki adalah .727 dengan validitas butir berkisar dari .508 hingga .597. Pada reliabilitas orientasi ekstrinsik personal, koefisien Alpha Cronbach yang dimiliki adalah sebesar .701 dengan validitas butir berkisar dari 384 hingga .612. pada Reliabilitas dimensi ekstrinsik secara keseluruhan memiliki koefisien Alpha Cronbach sebesar .711 dengan validitas butir berkisar antara .391 hingga .566.

Untuk mengukur agresivitas dalam penelitian ini, peneliti menggunakan Verbal Aggressiveness Scale (VAS) yang dikembangkan oleh Infante dan Wigley pada tahun 1986, dan seiring perkembangannya, terdapat perdebatan apakah skala ini merupakan multidimensi atau unidimensi (Croucher, DeMaris, Turner, \& Spencer, 2013). Dengan adanya ketidakpastian tersebut, pada akhirnya banyak penelitian yang hanya menggunakan 10 butir yang merupakan butir non reverse (Anderson \& Martin; Chesboro \& Martin; Martin \& Anderson; Myers \& Johnson, dalam Croucher dkk., 2013). Dalam penelitian ini, peneliti pun akan menggunakan 10 butir seperti yang dilakukan oleh beberapa peneliti sebelumnya.

Setelah diadaptasi, VAS memiliki reliabilitas dengan koefisien Alpha Cronbachsebesar .725 dengan validitas butir berkisar antara .064 hingga .531. Menurut Anastasia dan Urbina (2007), batas penerimaan nilai validitas butir adalah .2. Berdasarkan batas nilai tersebut terdapat 1 butir yang memiliki validitas butir di bawah .2, sehingga butir tersebut dieliminasi. Butir yang dieliminasi 
adalah "Ketika tidak ada satu hal pun yang terlihat ampuh dalam usaha mempengaruhi orang lain, saya akan berteriak dan menjerit untuk mendapatkan beberapa pergerakan respon dari mereka" (butir kesembilan). Setelah butir tersebut dieliminasi, nilai reliabilitas Alpha Cronbach yang dimiliki sebesar .748 dengan validitas butir berkisar antara .226 hingga .514 .

\section{ANALISIS DAN HASIL}

Kuesioner yang disebarkan berjumlah 105 kuesioner. Namun, dikarenakan terdapat 18 kuesioner yang datanya tidak dapat digunakan karena tidak sesuai dengan kriteria inklusif penelitian, jumlah kuesioner yang digunakan dalam pengolahan data ialah 87 data.

Uji korelasi menunjukkan tidak adanya korelasi antara agresivitas dengan orientasi religiositas intrinsik $(r=-.032, p=.768)$, namun terdapat korelasi positif yang signifikan antara agresivitas dengan orientasi religiositas ekstrinsik $(r=.271, p=.011)$. Dengan mengacu kepada hasil tersebut, maka dapat disimpulkan bahwa $H_{1}$ ditolak dan $H_{2}$ diterima.

Tabel 1.

Uji Korelasi

\begin{tabular}{llccc}
\hline & Agresivitas & $\begin{array}{c}\text { Orientasi } \\
\text { Religiositas } \\
\text { Intrinsik }\end{array}$ & $\begin{array}{c}\text { Orientasi Religiositas } \\
\text { Ekstrinsik }\end{array}$ \\
\hline Agresivitas & & & & \\
\hline $\begin{array}{l}\text { Orientasi } \\
\text { Intrinsik }\end{array}$ & Religiositas & -.032 & & \\
\hline $\begin{array}{l}\text { Orientasi } \\
\text { Ekstrinsik }\end{array}$ & Religiositas & $.271 *$ & .050 & \\
\hline
\end{tabular}

Ket.: *signifikan pada tingkat signifikansi .05

\section{DISKUSI}

Tidak adanya korelasi antara orientasi religiositas intrinsik dengan agresivitas dapat dijelaskan dengan karakteristik responden dalam penelitian ini. Individu dalam penelitian ini berada pada tahap emerging adulthood. Pada emerging adulthood, individu sedang memasuki masa transisi dari remaja menuju kepada dewasa muda (Arnett, 2004). Pada masa transisi, individu belum sepenuhnya memiliki karakteristik individu dewasa muda dan baru memulai untuk memilikinya. Papalia dan Feldman (2012) mengungkapkan bahwa individu pada masa dewasa memiliki reflective thinking, yang merupakan proses pemikiran yang melibatkan evaluasi akan informasi dan juga kepercayaan secara aktif dengan memandang dari bukti dan juga implikasi yang ada. Sebagaimana individu yang berada pada masa emerging adulthood masih berada di masa transisi, dapat dikatakan 
pula bahwa individu pada masa emerging adulthood baru memulai proses pemikiran tersebut. Hal tersebut tidak menutup kemungkinan bahwa individu belum sepenuhnya mampu untuk mengevaluasi informasi yang diperoleh. Kondisi tersebut juga dapat turut memengaruhi bagaimana individu menginternalisasi nilai agama yang diajarkan.

Fowler (1981) mengungkapkan bahwa sebelum individu dapat menginternalisasi nilai ajaran agama, individu mengenal dan memahami konsep agama, Tuhan, dan kepercayaan yang dimiliki berdasarkan apa yang diceritakan atau apa yang disampaikan kepada individu dan cenderung menerima kepercayaan yang ada secara literal. Papalia dan Feldman (2012) juga mengungkapkan bahwa sebelum individu melakukan internalisasi, individu biasanya memiliki iman yang disesuaikan dengan standar yang ada pada komunitas yang dimiliki tanpa mempertanyakannya atau mengkritisinya terlebih dahulu. Individu dalam penelitian ini mungkin saja masih memiliki karakteristik-karakteristik yang telah disebutkan, yang mana individu belum melakukan internalisasi sepenuhnya.

Alim (2006) mengungkapkan bahwa internalisasi nilai agama merupakan suatu proses penyerapan nilai agama sehingga individu dapat bertindak berdasarkan ajaran agama tersebut. Hal tersebut dapat terjadi melalui adanya pemahaman yang utuh akan ajaran atau nilai agama yang ada, kesadaran akan pentingnya nilai atau ajaran agama, serta adanya kemungkinan untuk merealisasikan ajaran atau nilai agama tersebut dalam kehidupan sehari-hari.

Untuk individu dapat benar-benar menginternalisasi nilai agama atau ajaran agama yang ada, individu bukan hanya perlu menerima nilai agama secara literal atau pun dengan mengikuti standar ideal yang ada, namun juga perlu memiliki pemahaman yang utuh. Salah satu cara untuk mendapatkannya adalah dengan mendalami dan mengkritisi ajaran agama serta merealisasikannya. Dalam penelitian ini, meski tidak ditelusuri secara spesifik, diperkirakan tahap internalisasi yang ada baru sebatas penerimaan dan belum sampai kepada penghayatan yang seutuhnya, mengingat karakteristik dari responden yang merupakan pada tahap transisi untuk memulai internalisasi tersebut.

Selain itu, Piaget (dalam Santrock, 2003) mengungkapkan bahwa egosentrisitas remaja terwujud dalam keyakinan mereka pada kekuatan pemikiran yang dimiliki, yang mana remaja menganggap bahwa pemikiran mereka yang paling benar dan dunia harus mengikuti skema idealistik yang mereka miliki daripada mengikuti sistem realitas. Individu pada emerging adulthood berada pada masa transisi, yang mana tidak menutup kemungkinan bahwa individu juga masih memiliki pemikiran yang lebih idealistik. Individu yang memiliki usia lebih dekat dengan usia remaja (sekitar 18-19 tahun) dapat memiliki karakteristik yang lebih mirip dengan remaja, sehingga 
tidak menutup kemungkinan bahwa individu masih memiliki pemikiran yang idealistik, yang mana dapat turut memengaruhi hasil dari penelitian ini.

Kemudian, Thorson dan Powell (1990), melalui sampel penelitian yang lebih umum (anggota organisasi sipil, individu yang sedang melanjutkan studi dalam bidang pendidikan, dan juga siswa; tanpa ada tempat spesifik seperti dalam gereja), menunjukkan bahwa individu dengan usia yang lebih tua cenderung memiliki motivasi religiositas intrinsik yang lebih tinggi, walaupun pada usia tertentu, di mana individu sudah memasuki usia lanjut, motivasi religiositas intrinsik individu pun menurun. Penelitian yang dilakukan oleh peneliti berada di dalam lingkungan gereja dan bahkan pengambilan data pun dilakukan di dalam gereja. Hal tersebut dapat saja memberikan pengaruh, seperti terdapatnya stigma atau semacam tuntutan untuk individu memiliki kedekatan dengan Tuhan atau menerapkan nilai-nilai keagamaan yang ada. Kondisi demikian dapat menjadi salah satu keterbatasan penelitian ini.

Beralih dari orientasi religiositas intrinsik, terdapatnya korelasi positif yang signifikan antara orientasi religiositas ekstrinsik dengan agresivitas dapat dijelaskan melalui karakteristik individu yang memiliki orientasi religiositas ekstrinsik, yakni menggunakan agama untuk kepentingan dan keuntungan diri sendiri, seperti untuk kenyamanan diri sendiri, status, atau lingkungan sosial (Allport \& Ross, dalam Holdcroft, 2006). Individu berorientasi religiositas ekstrinsik tidak melakukan internalisasi akan nilai-nilai agama yang diajarkan dalam agama. Oleh karenanya, tidak menutup kemungkinan bahwa individu juga tidak menginternalisasi ajaran mendasar dari agama Kristen, yakni kasih (Candawasa, 2013). Dengan tidak meginternalisasi ajaran agama akan membuat individu dapat memiliki kemungkinan lebih besar untuk berperilaku tidak berdasarkan prinsip kasih, seperti perilaku agresif.

Sebagaimana individu menggunakan agama untuk keuntungan diri sendiri, maka individu akan berusaha dengan keras untuk dapat tetap diterima dalam lingkungannya, yang dalam konteks ini adalah komunitas pemuda gereja. Keinginan untuk diterima ini dapat menjadi suatu hal yang membuat individu melakukan konformitas (Myers, 2013).

\section{SIMPULAN DAN SARAN}

\section{Simpulan}

Dalam analisis ditemukan bahwa tidak terdapat korelasi yang signifikan antara orientasi religiositas intrinsik dengan agresivitas pada komunitas pemuda gereja. Selain itu, terdapat korelasi positif yang signifikan antara orientasi religiositas ekstrinsik dengan agresivitas pada komunitas pemuda gereja. 


\section{Saran Teoretis}

Penelitian selanjutnya sebaiknya melakukan penelitian dengan mempertimbangkan faktor atau variabel lain yang turut dapat memberikan pengaruh kepada orientasi religiositas maupun agresivitas individu, seperti biopsychosocial-spiritual model. Tidak hanya berkisar pada area sosial dan spiritual, namun juga melihat individu sebagai pribadi dengan kondisi psikologis yang berbedabeda yang juga dapat memberikan pengaruh terhadap orientasi religiositas dan agresivitas yang dimiliki. Hal tersebut diperkirakan akan memberi kontribusi penting untuk mengetahui peran kepribadian dalam memediasi hubungan orientasi religiositas ekstrinsik dengan agresivitas.

\section{Saran Praktis}

Bagi komunitas pemuda gereja A, diharapkan dapat lebih memahami bahwa terdapat faktor lain yang dapat memengaruhi agresivitas seseorang, yakni lingkungan yang dimiliki. Hal tersebut juga akan berpengaruh kepada cara penanganan, yang tidak hanya berfokus kepada diri individu yang melakukan tindakan agresif, namun juga lingkungan individu tersebut. Selain itu, dapat pula dilakukan pembinaan dan upaya internalisasi ajaran agama yang lebih mendalam untuk mengarahkan jemaat kepada pemikiran bahwa tidak cukup hanya menggunakan agama untuk keperluan atau keuntungan diri sendiri. Bagi masyarakat umum, diharapkan untuk dapat memiliki pandangan yang lebih terbuka bahwa agama tidak pasti akan membuat individu berperilaku baik dan tidak agresif. Namun, bila agama tidak dilandasi dengan orientasi yang sesuai, maka perilaku individu belum tentu menjadi lebih baik.

\section{REFERENSI}

Alim, M. (2006). Pendidikan agama Islam: Upaya pembentukan pemikiran dan kepribadian Muslim. Bandung: Remaja Rosdakarya.

Allport, G. W. (1950). The individual and his religion. New York, NY: MacMillan.

Anastasia, A., \& Urbina, S. (2007). Tes psikologi (R. H. S. Imam, penerj). Jakarta: Indeks.

Ancok, D., \& Suroso, F. N. (2001). Psikologi Islami. Yogyakarta: Pustaka Pelajar.

Ariyani, N. (2012). Kekerasan di Media Televisi. Ditemu kembali dari http://www.kpi.go.id/index.php/terkini/22-literasi-media/30824-kekerasan-di-media-televisi

Arnett, J. J. (2004). Emerging adulthood: The winding road from the late teens through the twenties. New York, NY: Oxford University Press. 
Candawasa, Y. (2013). Intisari Iman Kristen. Ditemu kembali dari http://tokyo.giiijapan.org/sermon/intisari-iman-kristen/

Croucher, S. M., DeMaris, A., Turner, J. S., \& Spencer, A. (2013). Assessing the factorial complexity of the verbal aggressiveness scale. Human Communication, 15(4), 261-277.

Daly, J. A. (2002). Personality and interpersonal communication. Dalam M. L. Knapp \& J. A. Daly (Eds.), Handbook of Interpersonal Communication (3rd ed., pp. 133-180). Thousand Oaks, CA: Sage.

Flannery, R. B. (1997). Violence in america. New York, NY: Continuum.

Fowler, J. W. (1981). Stages of faith: The psychology of human development and the quest for meaning. San Francisco, SF: Harper \& Row.

Geen, R. G. (1990). Human aggression. Milton Keynes, UK: Open University Press.

Gorsuch, R. L., \& McPherson, S. E. (1989). Intrinsic/extrinsic measurement: I/E-revised and singleitem scales. Journal for the Scientific Study of Religion, 28(3), 348-354. doi: $10.2307 / 1386745$

Green, H. (1972). Why churches die: A guide to basic Evangelism and church growth. Minneapolis, $\mathrm{MN}$ : Bethany Fellowship.

Holdcroft, B. (2006). What is religiosity? Catholic education: A Journal of inquiry and practice, 10(1), 89-103.

Kerlinger, F. N., \& Lee, H. B. (2000). Foundations of behavioral research (4th ed.). Fort Worth, TX: Harcourt College.

Muslim, A. R. (2016). Setiap hari ada 2 hingga 4 prt alami kekerasan. Ditemu kembali dari http://news.liputan6.com/read/2435803/setiap-hari-ada-2-hingga-4-prt-alami-kekerasan

Myers, D. G. (2013). Social psychology. (11th ed). New York, NY: MCGraw-Hill.

Papalia, D. E., \& Feldman. R. D. (2012). Experience human development (12th ed.). New York, NY: McGraw-Hill.

Santrock, J. W. (2003). Adolescence Perkembangan Remaja (6th ed.) (S. B. Adelar \& S. Saragih, Trans.; W. C. Kristiaji \& Y. Sumiharti, Eds.). Jakarta: Erlangga.

Sarwono, S. W. (2005). Teori-teori psikologi sosial. Yogyakarta: Rajawali Pers.

Steensland, B., Robinson, L. D., Wilcox, W. B., Park, J. Z., Regnerus, M. D., \& Woodberry, R. D. (2000). The measure of american religion: Toward improving the state of the art. Social Forces, 79(1), 291-318.

Thorson, J. A., \& Powell, F. C. (1990). Meanings of death and intrinsic religiosity. Journal of Clinical Psychology, 46(4), 379-391. doi: 10.1002/1097-4679(199007)46:43.0.co;2-a 
Umasugi, S. C. (2013). Hubungan antara regulasi emosi dan religiositas dengan kecenderungan perilaku bullying pada remaja. Emphaty, 2(1), 863-881.

Watkins, S. (2003). Religiosity and aggression in college students. Johnson City, Tennessee, TN: East Tennessee State University. 